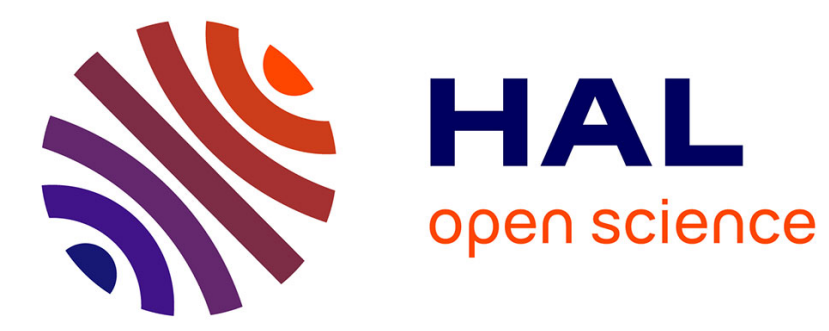

\title{
Tropical sources and sinks of carbonyl sulfide observed from space
}

\author{
N. Glatthor, M. Höpfner, I. T. Baker, J E Berry, J. E. Campbell, S. R. Kawa, \\ G P Krysztofiak, A. Leyser, B.-M. Sinnhuber, G. P. Stiller, et al.
}

\section{To cite this version:}

N. Glatthor, M. Höpfner, I. T. Baker, J E Berry, J. E. Campbell, et al.. Tropical sources and sinks of carbonyl sulfide observed from space. Geophysical Research Letters, 2015, 42 (22), pp.10082-10090. 10.1002/2015GL066293 . insu-01363835

\section{HAL Id: insu-01363835 https://hal-insu.archives-ouvertes.fr/insu-01363835}

Submitted on 1 Dec 2016

HAL is a multi-disciplinary open access archive for the deposit and dissemination of scientific research documents, whether they are published or not. The documents may come from teaching and research institutions in France or abroad, or from public or private research centers.
L'archive ouverte pluridisciplinaire HAL, est destinée au dépôt et à la diffusion de documents scientifiques de niveau recherche, publiés ou non, émanant des établissements d'enseignement et de recherche français ou étrangers, des laboratoires publics ou privés. 


\section{Geophysical Research Letters}

\section{RESEARCH LETTER \\ 10.1002/2015GL066293 \\ Tropical sources and sinks of carbonyl sulfide observed from space}

Key Points:

- First comprehensive global data set of upper tropospheric COS

- Detection of a tropical sink of COS

- Highest COS amounts above the Maritime Continent and the tropical western Pacific

Supporting Information:

- Figures S1 - S6 and Text S1

Correspondence to:

N. Glatthor,

norbert.glatthor@kit.edu

\section{Citation:}

Glatthor, N., et al. (2015), Tropical sources and sinks of carbonyl sulfide observed from space, $\mathrm{Geo}$ phys. Res. Lett., 42, 10,082-10,090, doi:10.1002/2015GL066293.

Received 22 SEP 2015 Accepted 4 NOV 2015 Accepted article online 10 NOV 2015 Published online 25 NOV 2015

C2015. American Geophysical Union. All Rights Reserved.

\section{Introduction} oxic soils and COS loss through reaction with the hydroxyl radical. et al., 2008; Suntharalingam et al., 2008; Berry et al., 2013].

\author{
N. Glatthor ${ }^{1}$, M. Höpfner ${ }^{1}$, I. T. Baker ${ }^{2}$, J. Berry ${ }^{3}$, J. E. Campbell ${ }^{4}$, S. R. Kawa ${ }^{5}$, G. Krysztofiak ${ }^{6}$, \\ A. Leyser ${ }^{1}$, B.-M. Sinnhuber ${ }^{1}$, G. P. Stiller ${ }^{1}$, J. Stinecipher ${ }^{7}$, and T. von Clarmann ${ }^{1}$ \\ ${ }^{1}$ Karlsruher Institut für Technologie, Institut für Meteorologie und Klimaforschung, Karlsruhe, Germany, ${ }^{2}$ Atmospheric \\ Science Department, Colorado State University, Fort Collins, Colorado, USA, ${ }^{3}$ Department of Global Ecology, Carnegie \\ Institution, Stanford, California, USA, ${ }^{4}$ Sierra Nevada Research Institute, University of California, Merced, California, USA, \\ ${ }^{5}$ NASA Goddard Space Flight Center, Greenbelt, Maryland, USA, ${ }^{6}$ University of Orléans, LPC2E, CNRS, Orléans, France, \\ ${ }^{7}$ Environmental Systems Graduate Group, University of California, Merced, California, USA
}

Carbonyl sulfide (COS) is the most prevalent sulphur compound in the atmosphere. As the main precursor gas of the stratospheric background aerosol layer, it directly affects global climate [Crutzen, 1976; Brüh/ et al., 2012]. In most of the recent estimations, the nearly closed budget of Kettle et al. [2002] has been taken as starting point (Table 1). This budget is based on best estimates from updated models and on the compilation of Watts [2000], when no updated model data were available. In this assessment the direct flux of COS from the oceans as well as the indirect flux via outgassing and subsequent oxidation of dimethyl sulfide is highest at middle to high latitudes during spring and summer, while indirect oceanic release via carbon disulfide $\left(\mathrm{CS}_{2}\right)$ is assumed to occur at low latitudes. Vegetation uptake is largest during the growing season. Other major sources are anthropogenic emissions, either directly or indirectly via $\mathrm{CS}_{2}$. Additional sinks are COS uptake by

However, according to subsequent assessments by Sandoval-Soto et al. [2005] and Montzka et al. [2007], vegetation uptake is up to 5 times higher than estimated in Kettle et al. [2002] (Table 1). This assumption has been confirmed by comparison of ground-based and airborne COS measurements with model simulations, where a twofold to fourfold increase of vegetation uptake was necessary to match the observations [Campbell

Because of the similarities of $\mathrm{CO}_{2}$ and $\mathrm{COS}$ uptake by plants and the-under normal atmospheric conditions - irreversibility of this process for the latter compound, COS has been suggested as cotracer for estimation of gross primary production (GPP) [Montzka et al., 2007; Blake et al., 2008; Campbell et al., 2008]. Analysis of GPP and of total ecosystem respiration provides important information about net ecosystem exchange of $\mathrm{CO}_{2}$, i.e., carbon exchange between the atmosphere and the biosphere. A first investigation of the suitability of COS as cotracer for GPP has been presented in Blonquist et al. [2011]. Use of COS for this estimation requires good knowledge on its distribution, but there are nearly no observations with global 
Table 1. Global Integrated COS Fluxes $\left(\mathrm{Gg} \mathrm{S} \mathrm{a}^{-1}\right)$ of Different Budget Estimations

\begin{tabular}{lccccc} 
& $\begin{array}{c}\text { Kettle et al. } \\
{[2002]^{\mathrm{a}}}\end{array}$ & $\begin{array}{c}\text { Montzka et al. } \\
{[2007]}\end{array}$ & $\begin{array}{c}\text { Suntharalingam et al. } \\
{[2008]^{\mathrm{b}}}\end{array}$ & $\begin{array}{c}\text { Berry et al. } \\
{[2013]^{\mathrm{c}}}\end{array}$ & $\begin{array}{c}\text { Kettle et al. } \\
\text { Modified }^{\mathrm{d}}\end{array}$ \\
\hline $\begin{array}{l}\text { Anthropogenic } \\
\text { direct and indirect }\end{array}$ & $90-266(177)$ & $90-266$ & 180 & 180 & 177 \\
Biomass burning & $11-64(42)$ & $68-144$ & 42 & 136 & 42 \\
Ocean direct/indirect & $39-520(278)$ & $39-520$ & 230 & 876 & 992 \\
Other sources & & $13-119$ & & & \\
(wetland, soil) & & & & & \\
Uptake by plants & $210-270(238)$ & $730-1500$ & 490 & 355 & 127 \\
Uptake by soil & $74-180(127)$ & $74-180$ & 127 & 101 & 116 \\
Loss by reaction with $\mathrm{OH}$ & $82-110(116)$ & $82-110$ & $82-110$ & & \\
\hline
\end{tabular}

a Values in parentheses were used for the first EMAC simulation.

${ }^{b}$ Kettle et al. modified, with excess of sink over sources.

CFluxes used for the PCTM simulation presented here.

${ }^{d}$ Fluxes used for the second EMAC simulation. Plant uptake increased by a factor of 4 , balanced by increased oceanic emissions in the latitude band $20^{\circ} \mathrm{S}-20^{\circ} \mathrm{N}$, similar as in Berry et al. [2013].

coverage. Since the year 2000 the Earth System Research Laboratory of the National Oceanic and Atmospheric Administration (NOAA/ESRL) has performed in situ measurements of COS on a global network consisting of about a dozen stations [Montzka et al., 2007]. However, none of these stations is situated in continental tropical regions. Spaceborne measurements of COS by other instruments are rare or cover low latitudes only poorly [Farmer et al., 1987; Barkley et al., 2008; Kuai et al., 2014].

So far, observations of COS by the spaceborne Michelson Interferometer for Passive Atmospheric Sounding (MIPAS) have been reported for a restricted time period (August 2003) only [Burgess et al., 2004]. We analyze the global distribution of COS and its seasonal cycle by the use of the whole MIPAS data set covering the years 2002-2012. We compare the MIPAS observations with simulations of the Parameterized Chemical Transport Model (PCTM) [Kawa et al., 2004; Berry et al., 2013] and of the European Centre/Hamburg/Modular Earth Submodel System Atmospheric Chemistry (EMAC) model [Jöckel et al., 2006]. EMAC simulations are used to show the sensitivity of upper tropospheric $\operatorname{COS}$ to vegetation uptake.

\section{MIPAS Data Analysis}

MIPAS is an infrared limb-sounding instrument, which has been operated on board the Envisat satellite between 2002 and 2012 [Fischer et al., 2008]. It performed rearward scans through the atmosphere, covering the midinfrared spectral region between 685 and $2410 \mathrm{~cm}^{-1}(4.1-14.6 \mu \mathrm{m})$ with a spectral sampling of $0.025 \mathrm{~cm}^{-1}$ (2002 to 2004) and of $0.0625 \mathrm{~cm}^{-1}$ (2005 to 2012), respectively. Due to its high spectral resolution and the long pathlength through the atmosphere, the instrument is dedicated for the detection of atmospheric trace gases. Retrieval of the COS amounts presented here is performed in spectral windows covering the wave number range $839-876 \mathrm{~cm}^{-1}$. The inversion consists of nonlinear least squares fitting in a global-fit approach on a fine altitude grid [von Clarmann et al., 2003] constrained by Tikhonov's first-order smoothing operator [Tikhonov, 1963]. Fit parameters are the COS profile together with the profiles of the most important interfering gases $\mathrm{HNO}_{3}, \mathrm{CFC}-11$, and $\mathrm{O}_{3}$, as well as one atmospheric continuum profile and a height-independent radiance offset per spectral window. The total COS retrieval error for a single MIPAS scan is about $10 \%$ between 10 and $14 \mathrm{~km}$, if the spectroscopic error, which is generally purely systematic, is neglected. The vertical resolution in the troposphere and lower stratosphere is 4-6 km. The data presented here are seasonal averages of the period 2002-2012 at the $250 \mathrm{hPa}$ pressure level. Averaging was performed in $5^{\circ} \times 15^{\circ}$ latitude-longitude bins, which generally resulted in adding up of several hundred (see Figure S1 in the supporting information) individual COS profiles in a single bin leading to strongly reduced noise errors. However, due to interference of clouds the bins over the tropical land masses contain significantly less data points down to fewer than 10 values at the $250 \mathrm{hPa}$ level.

We validated the upper tropospheric COS measurements of MIPAS by comparison with airborne in situ data of the HIAPER (High-performance Instrumented Airborne Platform for Environmental Research) Pole-to-Pole 
Observations campaign [Wofsy et al., 2012], the Arctic Research of the Composition of the Troposphere from Aircraft and Satellite (ARCTAS) campaign [Fuelberg et al., 2010], the Intercontinental Chemical Transport Experiment-Phase B (INTEX-B) campaign [Molina et al., 2008], and with additional airborne data of the National Oceanic and Atmospheric Administration (NOAA) obtained above the midcontinental United States. Generally, the COS amounts measured by MIPAS agree well with the airborne data. The deviations are mostly less than 20 parts per trillion by volume (pptv) and increase to $50 \mathrm{pptv}$ or more on rare occasions only. A more detailed presentation of these intercomparisons is given as supporting information.

\section{Model Descriptions}

The PCTM [Kawa et al., 2004; Berry et al., 2013] is an offline version of the transport formulation used in the Goddard Earth Observing System (GEOS) general circulation model. The version used here is run at $2^{\circ} \times 2.5^{\circ}$ latitude-longitude resolution with 55 vertical levels extending up to $1 \mathrm{hPa}$, driven by assimilated meteorological data from GEOS-4 [Bloom et al., 2005]. This model framework has been widely used for transport simulations in the troposphere and stratosphere, producing generally good comparison with observations of, e.g., $\mathrm{CO}_{2}, \mathrm{CH}_{4}, \mathrm{SF}_{6}$, and $\mathrm{CH}_{3} \mathrm{CCl}_{3}$ at daily to multiannual time scales [Kawa et al., 2004; Patra et al., 2011]. COS simulations were initialized with a 1 year spin-up from homogenous initial conditions. The COS surface fluxes and photochemistry are described in Berry et al. [2013], including a new mechanistic model for leaf and soil COS uptake embedded in the SiB3 global carbon flux model [Baker et al., 2008]. This results in an increase of vegetation and soil uptake by a factor of 3 as compared to the fluxes in Kettle et al. [2002] (Table 1). The enhanced vegetation sink requires an additional inferred COS source, located mainly in the tropical oceans, to balance the budget in comparison to observations. This combination of fluxes and transport reproduces many key features of available in situ COS observations [Berry et al., 2013].

The EMAC model is a numerical chemistry and climate simulation system that includes submodels describing tropospheric and middle atmosphere processes and their interactions with oceans, land, and human influences [Joeckel et al., 2006; Kerkweg et al., 2006; Joeckel et al., 2010]. It uses the second version of the Modular Earth Submodel System (MESSy2) to link multi-institutional computer codes. The core atmospheric model is the fifth generation European Centre Hamburg general circulation model (ECHAM5) [Roeckner et al., 2006]. For the present study the model is run with a resolution of $\mathrm{T} 42\left(\sim 2.8^{\circ} \times 2.8^{\circ}\right)$ on 39 vertical hybrid pressure levels up to $0.01 \mathrm{hPa}$ with a time step of $600 \mathrm{~s}$. The Era-Interim reanalysis [Dee et al., 2011] of the European Centre for Medium-Range Weather Forecasts (ECMWF) is used to nudge the simulations from model level 4 to $24(900-10 \mathrm{hPa})$. The simulations are initialized with the COS field resulting from a 20 years run using the budget given in Kettle et al. [2002] and with a decennial spin-up. In order to do sensitivity tests, EMAC is run in a simple configuration. To reproduce the chemistry of COS, the monthly mean climatological concentrations of OH used in Patra et al. [2014] (version $\mathrm{OH}$ _0.99) are applied. These OH fields are based on the fields given in Spivakovsky et al. [2000] in the troposphere but scaled by 0.92. Stratospheric $\mathrm{OH}$ is taken from Takigawa et al. [1999] as described in the methods section in Patra et al. [2014]. Monthly mean concentrations of atomic oxygen and photolysis rates are taken from the EMAC output. The emission of the tracer is calculated offline by using the submodel OFFLEM [Kerkweg et al., 2006], which handles prescribed emissions. The first simulation presented here applies the emission scenario of Kettle et al. [2002] in its original setup, while the second is modified by enhancement of the tropical vegetation uptake by a factor of 4 and increased release from the tropical oceans for compensation. Focussing of the compensation to low latitudes is in accordance with the findings of Berry et al. [2013], who optimized the latitudinal distribution of the additional oceanic source by an inversion approach.

\section{Results}

In Figure 1 we show climatological global COS distributions at the $250 \mathrm{hPa}$ level measured by (left column) MIPAS and modeled by the (right column) PCTM. The pressure level of $250 \mathrm{hPa}$ corresponds to $\sim 9.7 \mathrm{~km}$ at high latitudes and to $\sim 11.0 \mathrm{~km}$ at the Equator. The PCTM data are displayed unmodified, because sensitivity checks showed that folding with MIPAS averaging kernels hardly changes the model data at the $250 \mathrm{hPa}$ level. The displayed seasonal time periods are averaged over the years 2002-2012 for the measurements and over the years 2003-2005 for the PCTM simulation. In each of the seasons, enhanced COS volume mixing ratios of more than 510 pptv were measured over wide tropical and subtropical regions. This enhancement is most pronounced in boreal summer and weakest in boreal winter. The strongest enhancement of COS was 

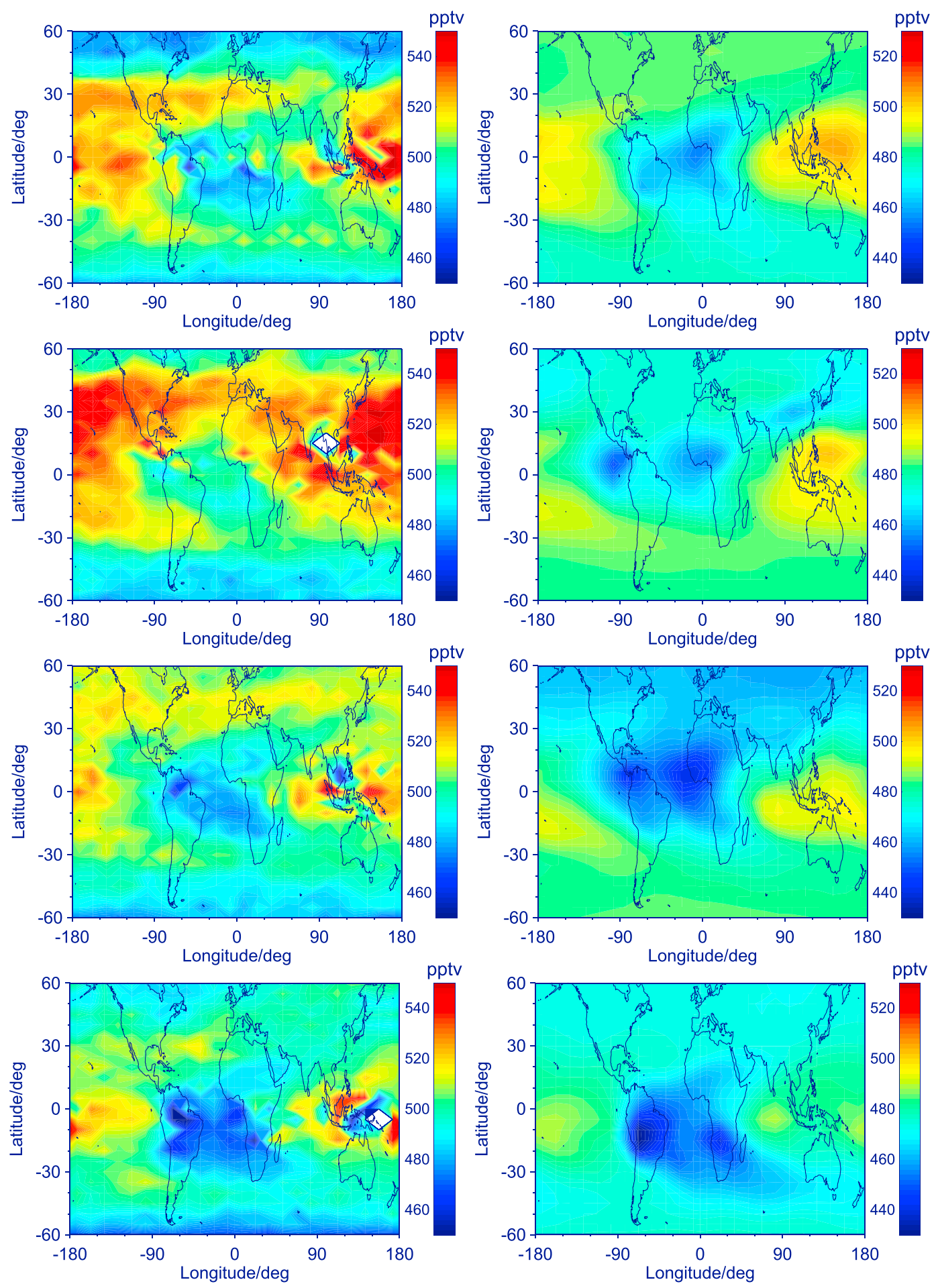

Figure 1. Climatological seasonal COS distributions at $250 \mathrm{hPa}$ measured by (left column) MIPAS and modeled by the (right column) PCTM. The data sets cover the years 2002-2012 (MIPAS) and 2003-2005 (PCTM), and the displayed seasons are March to May, June to August, September to November and December to February (top to bottom). White areas in Figure 1 (left column) are data gaps, and dark blue COS amounts above the Amazonian region (Figure 1, bottom left) are below 450 pptv. Because of a systematic bias between measurements and simulations, the color scale for representation of the model results is shifted by -20 pptv with respect to the scale used for measured COS. 
observed around Indonesia, above the tropical western Pacific, and during boreal summer also farther north above the western subtropical Pacific. Beside strong oceanic release, high upper tropospheric COS in these regions is also due to especially distinct deep convection. Modeled COS generally shows a similar distribution of elevated amounts at low latitudes with a similar seasonal variation, but the modeled COS volume mixing ratios are about 30 pptv lower than the measurements. Especially in boreal summer the area of measured high $\operatorname{COS}$ amounts extends farther north (up to $45^{\circ} \mathrm{N}$ ) than the respective model distribution. This points at additional sources not accounted for in the model or at an overestimation of the modeled sinks. A strong release of COS from the western part of the northern Pacific during boreal summer was, e.g., presented in Launois et al. [2015]. A potential additional source is increased rayon production mainly in China, which between 2002 and 2013 has grown by $140 \%$ [Campbell et al., 2015]. There are relatively similar features of enhanced low-latitude COS from oceanic release at the $150 \mathrm{hPa}$ level (not shown), which in the tropics corresponds to altitudes of 14-14.5 km. Slight differences are a higher portion of enhanced COS in the southern tropics and subtropics and observation of increased COS amounts in the area of the Asian monsoon anticyclone over South Asia and northern Africa in boreal summer.

As mentioned above, MIPAS COS amounts at northern midlatitudes exhibit a maximum during boreal summer, followed by 20 and 30 pptv lower values in boreal fall and winter, respectively. This decrease is considerably smaller and somewhat delayed in comparison to the decline observed at North American ground stations, which is attributed to vegetation uptake [Montzka et al., 2007]. Such an attenuation and slight temporal delay are confirmed by airborne measurements of COS in the upper troposphere above the United States also presented by Montzka et al. [2007]. A more detailed investigation of this topic is given in the supporting information.

A striking feature observed at low latitudes is a region of depleted COS amounts extending from the eastern coast of tropical South America over Brazil and the tropical Atlantic to Africa. A comparable observation has only been performed on one flight of the NASA TC4 campaign (tropical Latin and South America) on 8 August 2007 above the western Amazonian region [Berry et al., 2013], where the COS volume mixing ratios decreased to 400 pptv in the free troposphere and even to below 360 pptv in the boundary layer. The COS amounts are lowest, and the spatial extension of the depletion is largest between December and February, reaching eastward as far as the southern Indian Ocean and the Arabian peninsula. During this season the COS amounts decline to as low as 420 pptv above the Amazonian rain forest. The decline is weakest and spatially least extended between June and August. Generally, this feature is rather similar for every individual year during the observation period of MIPAS, and there is only little interannual variability (not shown). Any retrieval artifact caused by interference of the jointly fitted gases $\mathrm{HNO}_{3}, \mathrm{O}_{3}$, and CFC-11 as reason for the COS depletion can essentially be excluded by correlation analysis (see Figure S6). As mentioned in section 2, around $250 \mathrm{hPa}$ the sampling above the tropical continents is rather poor due to cloud contamination (see Figure S1). However, the sampling rate over the tropical Atlantic, where the uptake signal is also substantial, is much higher (50 to several hundred samples). Further, although somewhat attenuated, the depletion is also visible at the $150 \mathrm{hPa}$ level (not shown), where cloud contamination is less severe. Therefore, we exclude a sampling artifact as reason for the COS depletion as well. The PCTM distribution also exhibits a COS depletion, which agrees remarkably well with the measurements in spatial extension and in seasonal variation. The geographical location and seasonal cycle of the depletion strongly indicate that it is caused by vegetation uptake in tropical and subtropical South America, central, and southern Africa. The effect is largest in austral summer, when vegetation uptake in southern Amazonia [Baker et al., 2013; Lee et al., 2013; Parazoo et al., 2013] and presumably southern tropical Africa as well is strongest. Beside this large "COS hole" the measurements show a second region of low COS above Indonesia and South-East Asia, which also is the most distinct between December and February.

Figure 2 shows the corresponding global COS distributions at the $250 \mathrm{hPa}$ level of the two EMAC simulations. Like for the PCTM data, folding with MIPAS averaging kernels was not necessary for EMAC data from the $250 \mathrm{hPa}$ level. The first run, basing on the budget of Kettle et al. [2002], produced a weak tropical COS depletion only. Further, the COS amounts above the tropical source regions are about 30 pptv lower than the observations. The second run, in which the vegetation uptake was increased by a factor of 4 , resulted in a considerably stronger COS decrease extending from South America to Africa, which is more similar to the measurements and the PCTM simulation. Due to the enhanced oceanic release, the COS amounts above the source regions are about 20 pptv higher than in the first EMAC run. Similar as the PCTM distributions, the area of enhanced 

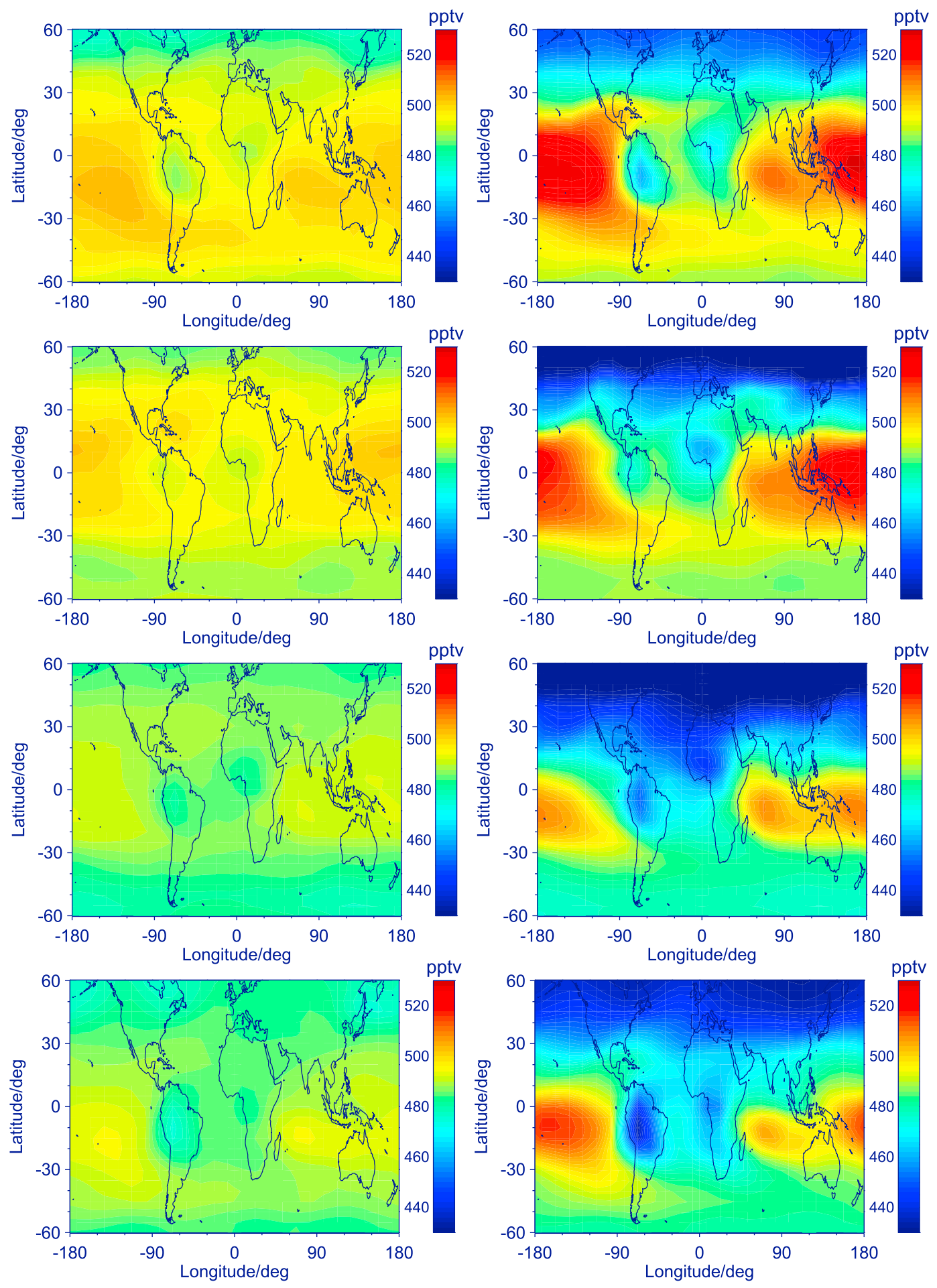

Figure 2. Climatological seasonal COS distributions at $250 \mathrm{hPa}$ modeled by EMAC using the (left column) Kettle fluxes and (right column) modified Kettle fluxes. The modification consists of an increase of the vegetation uptake by a factor of 4 and an enhancement of the COS release from the tropical oceans to close the budget. The data sets cover the years 2002-2012, and the displayed seasons are (top row) March to May, (second row) June to August, (third row) September to November, and (fourth row) December to February. The color scale is shifted by -20 pptv with respect to the scale used for measured COS in Figure 1 (left column). 

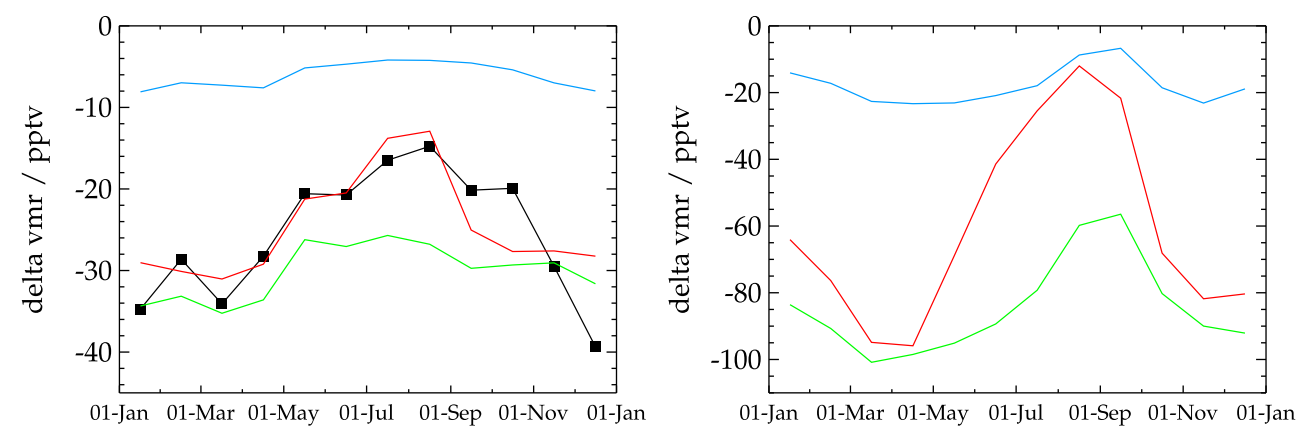

Figure 3. Monthly differences between $\operatorname{COS}$ amounts in the region of the $\operatorname{COS}$ depletion $\left(20^{\circ} \mathrm{S}\right.$ to $10^{\circ} \mathrm{N}, 75^{\circ} \mathrm{W}$ to $\left.25^{\circ} \mathrm{E}\right)$ and the rest of the latitude band. (left) Differences at $250 \mathrm{hPa}$ for MIPAS measurements (black curve), the PCTM simulation (red curve) on the basis of the budget described in Table 1, and two EMAC simulations. The EMAC simulations were performed basing on the budget in Kettle et al. [2002] (blue curve) and on a budget with vegetation uptake increased by a factor of 4 (green curve) (see also Table 1). (right) Differences from the same PCTM (red curve) and EMAC simulations (blue and green curves) as Figure 3 (left) but at $1000 \mathrm{hPa}$. Note the different vmr scales.

modeled COS does not extend as far north as the respective observations. As outlined above, this discrepancy points at potential deficiencies in modeled sources or sinks in this region.

For a more quantitative comparison of the measurements and the model results, Figure 3 (left) shows monthly averages of $\operatorname{COS}$ amounts at $250 \mathrm{hPa}$ in the region of the $\operatorname{COS}$ depletion $\left(20^{\circ} \mathrm{S}-10^{\circ} \mathrm{N}, 75^{\circ} \mathrm{W}-25^{\circ} \mathrm{E}\right)$. To roughly separate the signature of vegetation uptake from other processes relevant for the $\operatorname{COS}$ amounts in this latitude band (mainly oceanic release), the monthly averages of the rest of the latitude band were subtracted. Therefore, the curves are persistently negative. The measured differences are between -30 and -40 pptv from December to March, when vegetation uptake in the tropical and southern subtropical forests is highest and about -15 pptv in August. The respective differences of the PCTM model results agree very well with the measurements until September and show slightly larger deviations from October to December. The diagram also contains the results of the two EMAC simulations. As already mentioned above, the first run led to a much weaker $\mathrm{COS}$ depletion and thus to a small, seasonally only slightly varying difference. A stronger decrease and a larger seasonal variation of the difference could be achieved by increasing the vegetation uptake by a factor of 4. These sensitivity simulations with the EMAC model are a strong indication that the observed seasonal variation is caused by increased vegetation uptake, balanced by a corresponding rise in oceanic emissions.

Since during the season of maximum COS depletion (December to February), deep convection in the southern tropics also maximizes, we checked the model distributions at the Earth's surface to exclude a pure dynamic reason for the variation observed in the upper troposphere. Figure 3 (right) shows monthly differences at $1000 \mathrm{hPa}$ between simulated COS amounts of the same two regions. It is evident that modeled COS at $1000 \mathrm{hPa}$ is not constant during the year, but exhibits an even stronger seasonal variation than at $250 \mathrm{hPa}$, also minimizing in austral summer and fall and maximizing in austral winter and spring. This confirms the assumption that the effect observed at $250 \mathrm{hPa}$ is caused by seasonally varying vegetation uptake.

\section{Conclusions}

Our analysis demonstrates that global observations of COS by limb-sounding instruments, though restricted to the upper troposphere and above, contain valuable information about surface processes like source and sink regions. Comparison of the measurements with simulations of two different models helped to interpret the low-latitude $\operatorname{COS}$ distribution and revealed some remaining model deficiencies. About $30 \mathrm{pptv}$, lower model amounts in two of the simulations (PCTM and EMAC-Kettle) point at too weak sources. These discrepancies could be considerably reduced in the second EMAC run with the highest oceanic source. The farther northward extension of enhanced measured $\operatorname{COS}$ (up to $45^{\circ} \mathrm{N}$ ) as compared to the model results indicates the necessity to increase the oceanic model source or to strengthen additional sources not properly taken into account. The COS depletion observed between Brazil and Africa is well reproduced by two different models, when a much larger uptake than suggested in Kettle et al. [2002] is assumed. Detection of this tropical depletion underlines the need of additional $\operatorname{COS}$ measurements at low latitudes, e.g., required for potential 
Acknowledgments

The authors like to thank the European Space Agency for giving access to MIPAS level-1 data. Meteorological analysis data have been provided by ECMWF. This work is a contribution to the EU StratoClim project (grant 603557). Part of this work was supported by the German Federal Ministry of Education and Research through the project ROMIC-THREAT (BMBF-01LG1217B). We acknowledge provision of airborne in situ COS data of the HIPPO-campaign (E.L. Atlas, S.A. Montzka, and J.W. Elkins), the ARCTAS- and INTEX-B campaigns (D.R. Blake), and of the National Oceanic and Atmospheric Administration (S.A. Montzka and C. Sweeney). MIPAS COS data can be accessed via http://www.imk-asf.kit.edu/english/sat.php. use of COS as proxy for GPP. A combination of adequately placed ground stations in combination with spaceborne measurements of $\operatorname{COS}$ would be suited to extend our upper tropospheric observations down to the surface.

\section{References}

Baker, I. T., L. Prihodko, A. S. Denning, M. Goulden, S. Miller, and H. R. da Rocha (2008), Seasonal drought stress in the Amazon: Reconciling models and observations, J. Geophys. Res., 113, G00B01, doi:10.1029/2007JG000644.

Baker, I. T., et al. (2013), Surface ecophysiological behavior across vegetation and moisture gradients in tropical South America, Agric. For. Meteorol., 182-183, 177-188, doi:10.1016/j.agrformet.2012.11.015.

Barkley, M. P., P. I. Palmer, C. D. Boone, P. F. Bernath, and P. Suntharalingam (2008), Global distributions of carbonyl sulfide in the upper troposphere and stratosphere, Geophys. Res. Lett., 35, L14810, doi:10.1029/2008GL034270.

Berry, J., et al. (2013), A coupled model of the global cycles of carbonyl sulfide and $\mathrm{CO}_{2}$ : A possible new window on the carbon cycle, J. Geophys. Res. Biogeosci., 118, 842-852, doi:10.1002/jgrg.20068.

Blake, N. J., et al. (2008), Carbonyl sulfide (COS): Large-scale distributions over North America during INTEX-NA and relationship to $\mathrm{CO}_{2}$, J. Geophys. Res., 113, D09S90, doi:10.1029/2007JD009163.

Blonquist, J. M., Jr., S. A. Montzka, J. W. Munger, D. Yakir, A. R. Desai, D. Dragoni, T. J. Griffis, R. K. Monson, R. L. Scott, and D. R. Bowling (2011), The potential of carbonyl sulfide as a proxy for gross primary production at flux tower sites, J. Geophys. Res., 116, G04019, doi:10.1029/2011JG001723.

Bloom, S., A. da Silva, D. Dee, M. Bosilovich, and J.-D. Chern (2005), Documentation and validation of the Goddard Earth Observing System (GEOS) data assimilation system, version 4, Tech. Rep. Ser. on Global Model. and Data Assimilation, NASA/TM-2005-104606, vol. 26, NASA Goddard Space Flight Center, Greenbelt, Md.

Brühl, C., J. Lelieveld, P. J. Crutzen, and H. Tost (2012), The role of carbonyl sulphide as a source of stratospheric sulphate aerosol and its impact on climate, Atmos. Chem. Phys., 12, 1239-1253, doi:10.5194/acp-12-1239-2012.

Burgess, A. B., R. G. Grainger, and A. Dudhia (2004), Progress in the retrieval of sulphur species from MIPAS, in Proceedings of the 2004 Envisat and ERS Symposium (ESA SP-572), 6-10 Sept. 2004, Salzburg, Austria, edited by H. Lacoste and L. Ouwehand, pp. 1-8, ESA, Noordwijk, Netherlands.

Campbell, J. E., et al. (2008), Photosynthetic control of atmospheric carbonyl sulfide during the growing season, Science, 322(5904), 1085-1088, doi:10.1126/science.1164015.

Campbell, J. E., M. E. Whelan, U. Seibt, S. J. Smith, J. A. Berry, and T. W. Hilton (2015), Atmospheric carbonyl sulfide sources from anthropogenic activity: Implications for carbon cycle constraints, Geophys. Res. Lett., 42, 3004-3010, doi:10.1002/2015GL063445.

Crutzen, P. J. (1976), The possible importance of CSO for the sulphate layer of the stratosphere, Geophys. Res. Lett., 3, 73-76.

Dee, D. P., et al. (2011), The ERA-Interim reanalysis: Configuration and performance of the data assimilation system, Q. J. R. Meteorol. Soc., 137, 553-597, doi:10.1002/qj.828.

Farmer, C. B., O. F. Raper, and F. G. O'Callaghan (1987), Final Report on the First Flight of the ATMOS Instrument During the Spacelab 3 Mission, April 29 Through May 6, 1985, JPL Publ. 87-32a, Jet Propulsion Lab., California Inst. of Technol., Pasadena, Calif.

Fischer, H., et al. (2008), MIPAS: An instrument for atmospheric and climate research, Atmos. Chem. Phys., 8, 2151-2188, doi:10.5194/acp-8-2151-2008.

Fuelberg, H. E., D. L. Harrigan, and W. Sessions (2010), A meteorological overview of the ARCTAS 2008 mission, Atmos. Chem. Phys., 10, 817-842, doi:10.5194/acp-10-817-2010.

Kawa, S. R., D. J. Erickson III, S. Pawson, and Z. Zhu (2004), Global $\mathrm{CO}_{2}$ transport simulations using meteorological data from the NASA data assimilation system, J. Geophys. Res., 109, D18312, doi:10.1029/2004JD004554.

Kerkweg, A., R. Sander, H. Tost, and P. Jöckel (2006), Technical note: Implementation of prescribed (OFFLEM), calculated (ONLEM), and pseudo-emissions (TNUDGE) of chemical species in the Modular Earth Submodel System (MESSy), Atmos. Chem. Phys., 6, 3603-3609, doi:10.5194/acp-6-3603-2006.

Kettle, A. J., U. Kuhn, M. von Hobe, J. Kesselmeier, and M. O. Andreae (2002), Global budget of atmospheric carbonyl sulfide: Temporal and spatial variations of the dominant sources and sinks, J. Geophys. Res., 107(D22), 4658, doi:10.1029/2002JD002187.

Kuai, L., J. Worden, S. S. Kulawik, S. A. Montzka, and J. Liu (2014), Characterization of Aura TES carbonyl sulfide retrievals over ocean, Atmos. Meas. Tech., 7, 163-172, doi:10.5194/amt-7-163-2014.

Jöckel, P., et al. (2006), The atmospheric chemistry general circulation model ECHAM5/MESSy1: Consistent simulation of ozone from the surface to the mesosphere, Atmos. Chem. Phys., 6, 5067-5104, doi:10.5194/acp-6-5067-2006.

Jöckel, P., et al. (2010), Development cycle 2 of the Modular Earth Submodel System (MESSy2), Geosci. Model Dev., 3, 717-752, doi:10.5194/gmd-3-717-2010.

Launois, T., S. Belviso, L. Bopp, and C. G. Fichot (2015), A new model for the global biogeochemical cycle of carbonyl sulfide-Part 1: Assessment of direct marine emissions with an oceanic general circulation and biogeochemistry model, Atmos. Chem. Phys., 15, 2295-2312, doi:10.5194/acp-15-2295-2015.

Lee, J. E., et al. (2013), Forest productivity and water stress in Amazonia: Observations from GOSAT chlorophyll fluorescence, Proc. R. Soc. B, 280, 20130171, doi:10.1098/rspb.2013.0171.

Molina, L. T., S. Madronich, J. S. Gaffney, and H. B. Singh (2008), Overview of MILAGRO/INTEX-B campaign, IGAC Newslet., $38,2-15$.

Montzka, S. A., P. Calvert, B. D. Hall, J. W. Elkins, T. J. Conway, P. P. Tans, and C. Sweeney (2007), On the global distribution, seasonality, and budget of atmospheric carbonyl sulfide (COS) and some similarities to $\mathrm{CO}_{2}$, J. Geophys. Res., 112, D09302, doi:10.1029/2006JD007665.

Parazoo, N. C., et al. (2013), Interpreting seasonal changes in the carbon balance of southern Amazonia using measurements of XCO 2 and chlorophyll fluorescence from GOSAT, Geophys. Res. Lett., 40, 2829-2833, doi:10.1002/grl.50452.

Patra, P. K., et al. (2011), TransCom model simulations of $\mathrm{CH}_{4}$ and related species: Linking transport, surface flux and chemical loss with $\mathrm{CH}_{4}$ variability in the troposphere and lower stratosphere, Atmos. Chem. Phys., 11, 12,813-12,837, doi:10.5194/acp-11-12813-2011.

Patra, P. K., et al. (2014), Observational evidence for interhemispheric hydroxyl-radical parity, Nature, 513, 219-223, doi:10.1038/nature13721.

Roeckner, E., et al. (2006), Sensitivity of simulated climate to horizontal and vertical resolution in the ECHAM5 atmosphere model, J. Clim., $19,3771-3791$

Sandoval-Soto, L., M. Stanimirov, M. von Hobe, V. Schmitt, J. Valdes, A. Wild, and J. Kesselmeier (2005), Global uptake of carbonyl sulfide (COS) by terrestrial vegetation: Estimates corrected by deposition velocities normalized to the uptake of carbon dioxide $\left(\mathrm{CO}_{2}\right)$, Biogeosciences, 2, 125-132, doi:10.5194/bg-2-125-2005. 
Spivakovsky, C. M., et al. (2000), Three-dimensional climatological distribution of tropospheric OH: Update and evaluation, J. Geophys. Res., 105(D7), 8931-8980, doi:10.1029/1999JD901006.

Suntharalingam, P., A. J. Kettle, S. M. Montzka, and D. J. Jacob (2008), Global 3-D model analysis of the seasonal cycle of atmospheric carbonyl sulfide: Implications for terrestrial vegetation uptake, Geophys. Res. Lett., 35, L19801, doi:10.1029/2008GL034332.

Takigawa, M., M. Takahashi, and H. Akiyoshi (1999), Simulation of ozone and other chemical species using a Center for Climate System Research/National Institute for Environmental Studies atmospheric GCM with coupled stratospheric chemistry, J. Geophys. Res., 104(D11), 14,003-14,018, doi:10.1029/1998JD100105.

Tikhonov, A. (1963), On the solution of incorrectly stated problems and a method of regularization, Dokl. Akad. Nauk SSSR, $151,501$. von Clarmann, T., et al. (2003), Retrieval of temperature and tangent altitude pointing from limb emission spectra recorded from space by the Michelson Interferometer for Passive Atmospheric Sounding (MIPAS), J. Geophys. Res., 108(D23), 4736, doi:10.1029/2003JD003602. Watts, S. F. (2000), The mass budgets of carbonyl sulfide, dimethyl sulfide, carbon disulfide and hydrogen sulfide, Atmos. Environ., 34 , $761-779$.

Wofsy, S. C., et al. (2012), HIPPO NOAA Flask Sample GHG, Halocarbon, and Hydrocarbon Data (R_20121129), Carbon Dioxide Inf. Anal. Cent., Oak Ridge Natl. Lab., Oak Ridge, Tenn. [Available at http://dx.doi.org/10.3334/CDIAC/hippo_013, (Release 20121129).] 